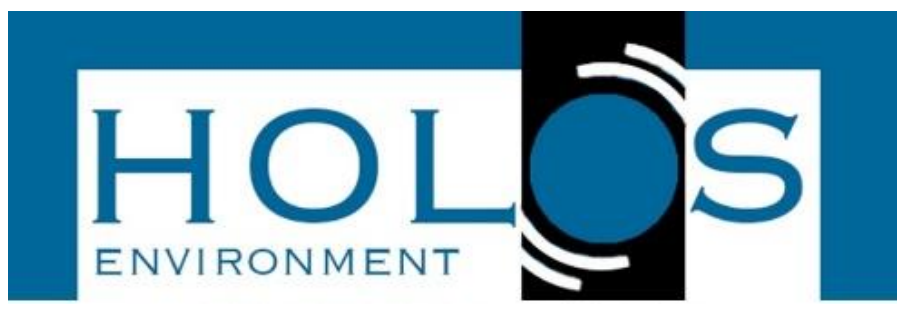

\title{
MÉTODO DO FLUTUADOR COMO FERRAMENTA PARA MONITORAMENTO DO COMPORTAMENTO HIDROLÓGICO DE CÓRREGO URBANO
}

\section{FLOATING METHOD AS A TOOL FOR MONITORING THE HYDROLOGICAL BEHAVIOR OF URBAN STREAM}

\author{
Cleiton Oliveira dos Santos ${ }^{1}$; Josenilson de Assis Ferreira ${ }^{1}$
}

Artigo recebido em: 13/09/2019 e aceito para publicação em: 21/11/2019.

DOI: http://dx.doi.org/10.14295/holos.v19i4.12355

Resumo: A água, recurso natural de extrema importância para a sobrevivência do homem, tem sido extraída de forma acelerada por diversos setores que têm interferido no ciclo, alterando a qualidade e quantidade da água. Muitos países já sofrem com a escassez hídrica, fazendo necessária a aplicação de legislações nacionais e internacionais para o controle das atividades que a usam e as resoluções de possíveis conflitos. No presente estudo foram realizados monitoramento e medição da vazão do córrego criminoso localizado na sub bacia do rio Taquari, utilizando o método flutuador para quantificar a vazão e réguas linimétrica para fazer o monitoramento diário da lamina d'água a fim de identificar os possíveis fatores que estão interferindo na vazão do córrego e produzir com os dados obtidos a curva chave tipo potência. Com base nos resultados obtidos o método flutuador mostrou-se adequada para medição de vazão de córregos com pouca quantidade d'água, a curva chave mostrou-se ajustado para medições diárias utilizando a cota da régua linimétrica com os parâmetros $h_{0}=0,11, a=907,7781$, e $\mathrm{m}=0,528$, o comportamento fluvial do córrego criminoso no período apresentou $Q_{90}$ de $115{\mathrm{~L} . \mathrm{S}^{-1}}^{\text {e }} \mathrm{Q}_{95}$ de 99 L.S $^{-1}$.

Palavras-chave: Recursos hídricos. Monitoramento de vazão. Método flutuador.

\begin{abstract}
Water, a natural resource of extreme importance for the survival of man, has been extracted in an accelerated way by several sectors that have interfered in the cycle, altering the quality and quantity of the water. Many countries already suffer from water scarcity, necessitating the application of national and international legislation to control the activities that use it and resolutions of possible conflicts. In the present study, monitoring and measurement of the flow of the criminal stream located in the sub basin of the Taquari River was carried out, using the float method to quantify the flow and linimetric rules for daily monitoring of the water sheet in order to identify the possible factors that are interfering in the flow of the stream and produce with the data obtained the key curve type power. Based on the results obtained, the float method proved to be adequate for flow measurement of streams with little amount of water, the key curve was adjusted for daily measurements using the linimetric ruler dimension with the parameters $h_{0}=0,11, a=907,7781$, at $=0.528$, the fluvial behavior of the criminal stream in the period showed Q90 de 115 L.S ${ }^{-1}$ and Q95 de 99 L.S ${ }^{-1}$.
\end{abstract}

Keywords: Water resources. Flow monitoring. Float method.

\footnotetext{
${ }^{1}$ Universidade Estadual de Mato Grosso do Sul (UFMS), Dourados, MS. E-mails: (ceo.cleiton@bol.com.br, josenilsonaf@hot$\underline{\text { mail.com) }}$
} 


\section{INTRODUÇÃO}

A água é um dos recursos naturais mais importantes da Terra, essencial para a sobrevivência do ser humano. Em esfera global, nos próximos séculos a demanda pela água possui tendência de aumentar por alguns setores como a agricultura, indústrias e a urbanização acelerada, sendo fatores interferentes no ciclo da água e sua disponibilidade, qualitativa e quantitativa (KONCAGÜL, 2017).

Atualmente, dois terço da população mundial sofrem com a falta de água pelo menos um mês por ano (KONCAGÜL, 2017), tornando esta escassez hídrica uma realidade em vários países, agravando-se devido à degradação ambiental que muda a característica de áreas produtivas aumentando o problema da disponibilidade da água (TUNDISI, 2008).

A grande preocupação causada pela escassez hídrica estimulou a reunião de governantes e representantes de diversos países, analisando e estudando solução para diminuir o problema da falta de água em nível de país, surgindo então a Conferencia Internacional sobre Água e Meio Ambiente, sendo este encontro organizado pela Organização das Nações Unidas (ONU) em Janeiro de 1992, na cidade de Dublin (Irlanda) (ONU, 1992a).

O Brasil tem o privilegio de ter grande disponibilidade hídrica, mas não é homogênea em suas regiões, sendo visível esta diferença quando comparado a Região Nordeste que tem uma deficiência hídrica com a Região Norte onde tem água abundante (BORBA \& BAYER, 2015). Os rios brasileiros em sua maioria são usados para abastecimento da população sendo de extrema necessidade o monitoramento hidrológico, levantando dados sobre a quantidade e qualidade desses recursos hídricos tanto superficiais quanto subterrâneo (ANA, 2017).

Em áreas urbanas faz se necessário um bom planejamento do uso e ocupação do solo para diminuir os impactos negativos nas bacias hidrográficas, (JOIA et al., 2017). Conhecer a vazão dos rios e córregos torna-se importante, pois a vazão representa todo volume d'água que passa por uma determinada seção por um período de tempo, e estão relacionados com o balanço hídrico que é o estudo do ciclo hidrológico, os tipos de uso e manejo do solo, podendo ser uma ferramenta importante nas tomadas de decisões e indicar pontos de entrada e saída de águas. É possível monitorar estas vazões com réguas linimétrica instaladas nas margens dos rios e córregos, 
também fazendo uso de métodos de medições (CARVALHO, 2008; SOUSA et al., 2015; BARRETO et al., 2014).

Alguns métodos de medição de vazão são relativamente caros, tornando difícil a realização de medições constantes em rios e córregos, (COLLISCHONN \& TASSI, 2008), ainda, com características diferentes, estes podem necessitar de medições diárias. Com a produção de uma curva chave torna-se viável, economicamente e em eventos críticos, usando as cotas diárias da régua linimétrica, determinar as vazões diárias, podendo ter uma maior compreensão da dinâmica fluvial (BARTELS et al., 2010; VANELLI et al., 2018).

Seguindo este contexto, o presente trabalho objetivou a realização do monitoramento do córrego criminoso descrevendo seu comportamento fluvial e a obtenção de uma curva-chave.

\section{REFERENCIAL TEÓRICO}

\subsection{Medição de vazão}

A medição de vazão é de extrema importância no estudo das bacias hidrográficas, principalmente as próximas de áreas urbanas, tendo em vista a crescente utilização dos recursos hídricos nos múltiplos usos da água. As medições também servem para estudar a disponibilidade dos recursos hídricos dentro da bacia e construir bancos de dados para estudos futuros (CABRAL et al., 2013; ALBUQUERQUE et al., 2018).

Existem várias metodologias aplicada na medição de vazão, algumas mais simples como a medição através do método do vertedor e flutuador, outros métodos mais precisos como os molinetes, ecosonda, doppler acústicos e até por satélites (CARVALHO, 2008).

\subsection{Método do flutuador}

O método flutuador consiste em medir a velocidade da água usando objetos flutuantes em trechos pré-determinados, recomenda-se o uso deste método principalmente em lugares que não dá para colocar materiais mais sofisticados como, por exemplo, o molinete fluviométrico, ou lugares com pouca disponibilidade hídrica. Os 
objetos usados na medição podem ser diversos, como laranja, garrafa plástica ou isopor, sendo muito criticado em seus resultados devido poder sofrer interferência do vento e usar em suas formulas um coeficiente para ajustar a velocidade média da seção, mas é um método de fácil compreensão, com um baixo custo para instalar e pode medir qualquer vazão em caráter de pré-avaliação (SANTOS et al., 2018).

Segundo Palhares et al. (2007), a fórmula de medição de vazão usando o método flutuador está demostrada na Equação 1.

$\mathrm{Q}=\frac{(A \times L \times C)}{T}\left(m^{3} \cdot s^{-1}\right)$,

onde: $A$ é média da área do rio, $L$ é o comprimento da área de medição, $C$ é o coeficiente ou fator de correção, T é o tempo que o flutuador leva para se deslocar no comprimento L.

\subsection{Régua linimétrica}

As cotas dos córregos e rios também podem ser observadas através de réguas instaladas na margem, sendo um processo barato mais, para sua instalação deve-se escolher uma seção de medição do rio ou córrego, com fácil acesso (ANA, 2016). Os modelos das réguas seguem um padrão, sendo elas régua linimétrica de alumínio, $P V C$ ou fibra de vidro, graduada a cada 1 centímetro $(\mathrm{cm})$ e numerada a cada $2 \mathrm{~cm}$, tem que ser instalada acompanhando a seção transversal do rio com um alinhamento perpendicular ao eixo do rio.

\subsection{Curva-chave}

A curva-chave tem papel fundamental dentro de uma bacia, ela é feita através de dados já coletados de medições de vazão comparados com os níveis da água que pode ser das réguas linimétrica instaladas nas margens dos corpos hídricos. É necessário fazer uma curva-chave confiável e de boa qualidade, podendo na maioria das vezes determinarmos vazões permitindo identificar eventos extremos, onde outros medidores de vazão não podem ser usados (BRUSA \& CLARKE, 1999; LIMA \& MACEDO, 2017; RIZZARDI et al., 2012). 


\subsection{Características fisiografica de bacias hidrográfica}

A bacia hidrográfica pode ser analisados de diferentes formas e realizados diversos estudos. A caracterização fisiográfica, permite identificar diversas informações na bacia, como retirada de mapas, sistema de informação geográfica, imagem de satélites, fotografia aérea. A caracterização da bacia é umas das primeiras informações levantadas e através desses estudos podem ser analisados outros aspectos tanto hidrológicos como ambientais, servindo futuramente de ferramenta que auxiliará em estudos de geologias, drenagem fluvial e outros (WENZEL, et al., 2017; CARVALHO et al., 2009).

\subsection{1 Área de Drenagem}

Área de drenagem é a principal característica que a bacia hidrográfica, representa a área delimitadas pelo divisor de água, atualmente sendo calculada através do Sistema de Informações Geográfica (SIG), cuja a unidade de medida usual é em $\mathrm{Km}^{2}$ (CARVALHO et al., 2009).

\subsubsection{Perímetro}

É o comprimento da linha do divisor de água que circunda toda a bacia hidrográfica, sendo calculado em Km (SILVA \& TONELLO, 2014).

\subsubsection{Comprimento talvegue}

O comprimento do talvegue é a distancia da foz até a montante, ou considerado a diferença do exultório e seu ponto mais afastado dentro da bacia (GALVíNCIO \& SOUSA, 2004; COLLISCHONN \& DORNELLES, 2013).

\subsubsection{Declividade do talvegue}

Segundo Santos et al. (2018), a declividade do talvegue é a diferença de altitude entre o ponto mais alto do trecho fluvial (nascente) e o mais baixo (foz), conforme 
apresentado na Equação 2, interferindo de forma direta na velocidade de escoamento da água e o tempo de concentração.

$S=\frac{H}{L} x 100$

Sendo: $\mathrm{S}=$ Declividade do curso de água (\%); H = Diferença de altitude (m); L = Comprimento do leito $(\mathrm{m})$.

\subsubsection{Coeficiente de Compacidade}

O coeficiente de compacidade representa a forma da bacia hidrográfica, sendo esta relação entre forma/perímetro, mostrando se a bacia circular ou mais alongada, conforme Equação 3 (SILVA \& TONELLO, 2014).

$K c=0,28 *\left[\frac{P}{\sqrt{A}}\right]$

Onde: $\mathrm{Kc}=$ Coeficiente de compacidade; $\mathrm{P}=$ Perímetro da bacia $(\mathrm{km}) ; \mathrm{A}=$ Área de Drenagem da bacia $\left(\mathrm{Km}^{2}\right)$.

\subsubsection{Fator de Forma}

$\mathrm{Na}$ Equação 4, o fator de forma compara a forma da bacia com um retângulo, levando em consideração a relação à razão da largura média e o comprimento da bacia, afetando diretamente no tempo de concentração da chuva dentro da bacia, indicando também a tendência para cheias (SANTOS et al., 2012).

$$
F=\frac{A}{L^{2}}
$$

Onde: $F=$ Fator de Forma; $A=$ Área de Drenagem da bacia $\left(\mathrm{km}^{2}\right) ; \mathrm{L}=$ Comprimento do eixo da bacia, da foz até o ponto mais longínquo do espigão $(\mathrm{km})$. 


\subsubsection{Densidade de Drenagem}

A densidade de drenagem correlaciona o comprimento total de todos os rios e córregos com a área da bacia hidrográfica, levando em consideração os rios e córregos perenes e temporários, mostrando o potencial da drenagem e a velocidade da água dentro da bacia. Calculando através da Equação 5:

$$
D d=\frac{L}{A}
$$

Sendo: $\mathrm{Dd}=$ Densidade de drenagem $\left(\mathrm{Km} \mathrm{ou} \mathrm{km}^{-2}\right) ; \mathrm{L}=$ Comprimento total dos rios ou canais $(\mathrm{km}) ; \mathrm{A}=$ Área de drenagem $\left(\mathrm{km}^{2}\right)$ (SILVA \& TONELLO, 2014).

\subsubsection{Tempo de Concentração Kirpch}

Tempo de concentração é o tempo que leva para a água da chuva que cai no ponto mais distante da bacia chegar ao exutório, contribuindo assim com o escoamento superficial de saída, sendo apresentado na Equação 6 (SANTOS et al., 2018).

$t_{c}=57 *\left(\frac{L}{\Delta h}\right)^{0,385}$

Sendo: Tc = Tempo de concentração (minutos); $L=$ Comprimento do leito principal $(\mathrm{km})$ e $\Delta \mathrm{h}=$ declividade do leito $\left(m \cdot \mathrm{m}^{-1}\right)$, (Collischonn \& Dornelles, 2013).

\section{PROCEDIMENTOS METODOLÓGICOS}

\section{1 Área de Estudo}

A micro bacia do Córrego Criminoso está localizada na Sub Bacia Hidrográfica do Rio Taquari, entre as coordenadas, $18^{\circ} 27^{\prime} 49,9^{\prime \prime}$ e $18^{\circ} 29^{\prime} 21^{\prime \prime}$ de latitude Sul, e 54은 43' 56,7' e 54 45' 13,9" de longitude Oeste, demostrado na Figura 1. O córrego é um afluente da margem direita do Rio Taquari ao norte do estado de Mato Grosso do Sul, com uma extensão de $5,5 \mathrm{~km}$ localizado próxima ao perímetro urbano do município de Coxim (GÜNTZEL et al., 2011). 
Figura 1 - Mapa de localização da micro bacia do córrego criminoso
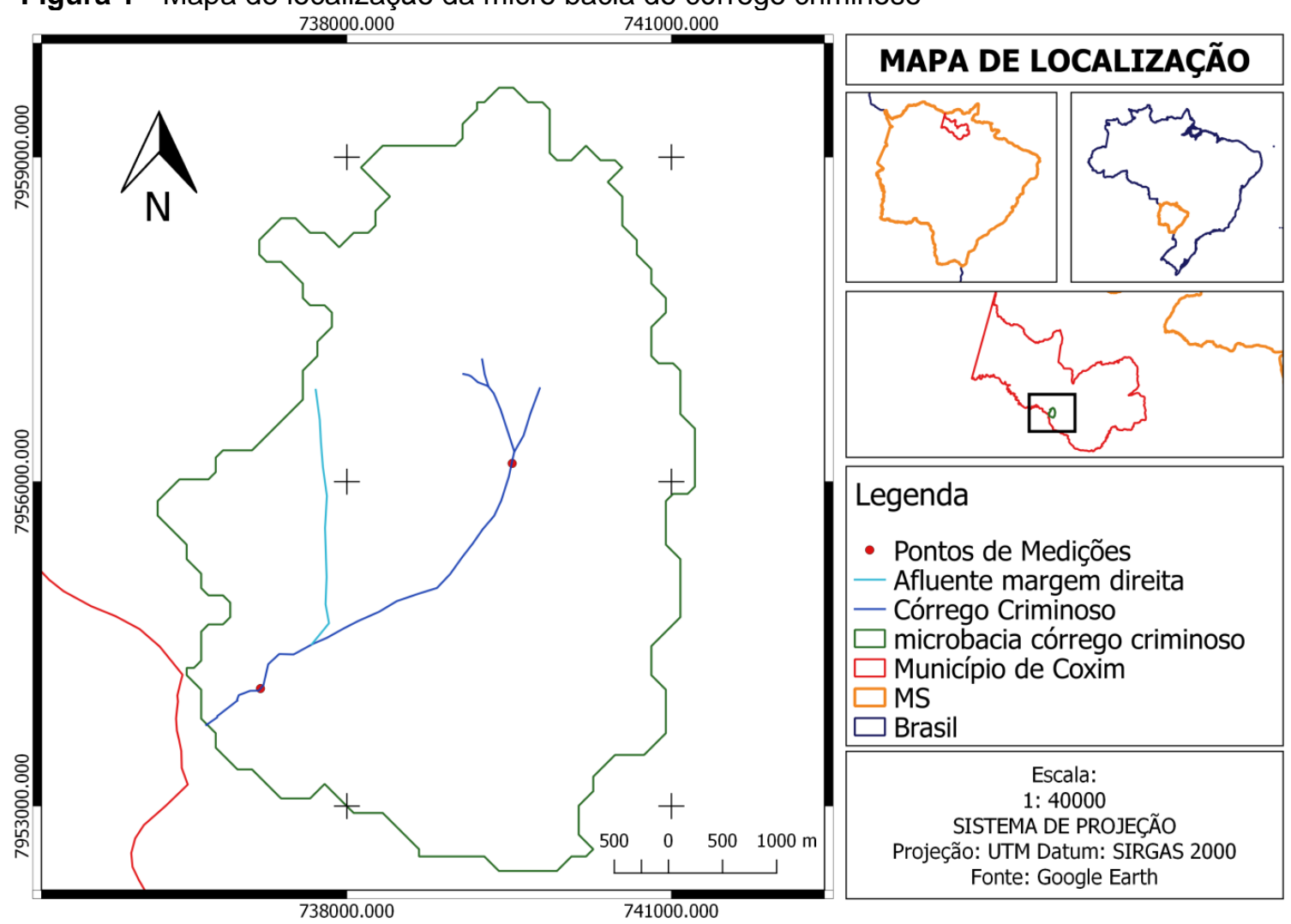

Legenda

- Pontos de Medições

Afluente margem direita

- Córrego Criminoso

$\square$ microbacia córrego criminoso

$\square$ Município de Coxim

MS

Brasil

Escala:
1: 40000

SISTEMA DE PROJEÇ̃̃O

Projeção: UTM Datum: SIRGAS 2000 Fonte: Google Earth

Fonte: Autoria própria

Segundo a Empresa Brasileira de Pesquisa Agropecuária (EMBRAPA, 2006) o solo em toda a micro bacia é Neossolo Quartzarênico conforme mostra a Figura 2, sendo que este tipo de solo ocupa aproximadamente $15 \%$ de toda a região Centro Oeste, apresentando características arenoso, bastante frágil e tem mudanças imediatas quando sofre interferência antrópicas, ainda tem baixa capacidade para reter água, muitas limitações para uso agrícola e o nível de alumínio está sempre em nível tóxicos (CARNEIRO et al., 2009).

O clima da região é predominante sub-úmido e semi-árido (Güntzel, et al., 2011), sendo que, as temperaturas variam de $23^{\circ} \mathrm{C}$ e $25^{\circ} \mathrm{C}$ podendo alcançar máximas de $45^{\circ} \mathrm{C}$ e mínimas de $07^{\circ} \mathrm{C}$, a precipitação anual oscila entre 900 a $1.100 \mathrm{~mm}$. Cemtec - MS (n.d.). 
Figura 2 - Tipo de solo na micro bacia do córrego criminoso

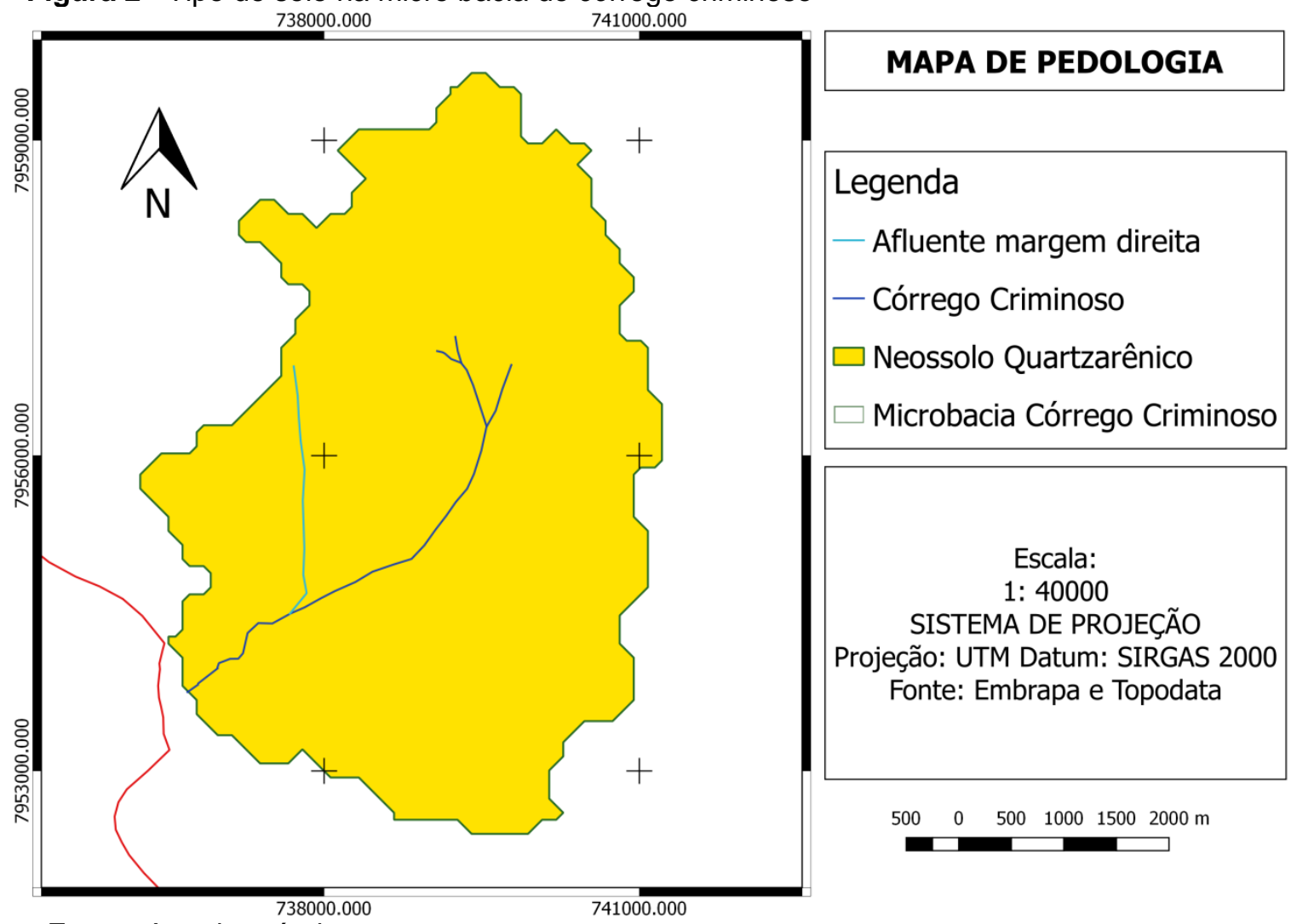

Fonte: Autoria própria

\subsection{Amostragem}

Utilizou-se o método flutuador conforme metodologia descrita por Palhares et al. (2007) e Bezerra et al. (2017), que calcula a vazão do córrego, usando equações para uma melhor precisão e podendo ser descrita seus resultados em metros cúbicos por segundo $\left(\mathrm{m}^{3} \cdot \mathrm{s}^{-1}\right)$. As medições tiveram inicio no mês de dezembro de 2017 até novembro de 2018 totalizando 12 medições, sendo realizada entre os dias 18 a 22 de cada mês, com tempo seco.

Para melhor interpretação o método foi dividido em etapas.

3.2.1 A Equação 7 apresenta os calculo para medição da vazão

$Q=\frac{A \times L \times C}{T}\left(m^{3} \cdot s^{-1}\right)$

Sendo assim:

$\mathrm{Q}=$ vazão. 
$A$ = média da área do rio (distância entre as margens multiplicada pela profundidade do rio).

$\mathrm{L}=$ comprimento da área de medição.

$C=$ coeficiente ou fator de correção $(0,8$ para rios com fundo pedregoso ou 0,9 para rios com fundo barrento). Este coeficiente permite a correção devido ao fato de a água se deslocar mais rápido na superfície do que na porção do fundo do rio. Multiplicando a velocidade da superfície pelo coeficiente de correção ter-se-á uma melhor medida da velocidade da água.

$\mathrm{T}=$ tempo, em segundos, que o flutuador leva para deslocar-se no comprimento $\mathrm{L}$.

\subsubsection{Seleção de um trecho do rio (L)}

$\mathrm{Na}$ escolha do trecho do córrego foi tomado alguns cuidados, segundo Bezerra et al. (2017) o trecho do rio deve ser reto (sem curvas), ter profundidade mínima de $15 \mathrm{~cm}$ e não ser uma área de águas paradas (Figura 3).

Figura 3 - Marcação do trecho do rio

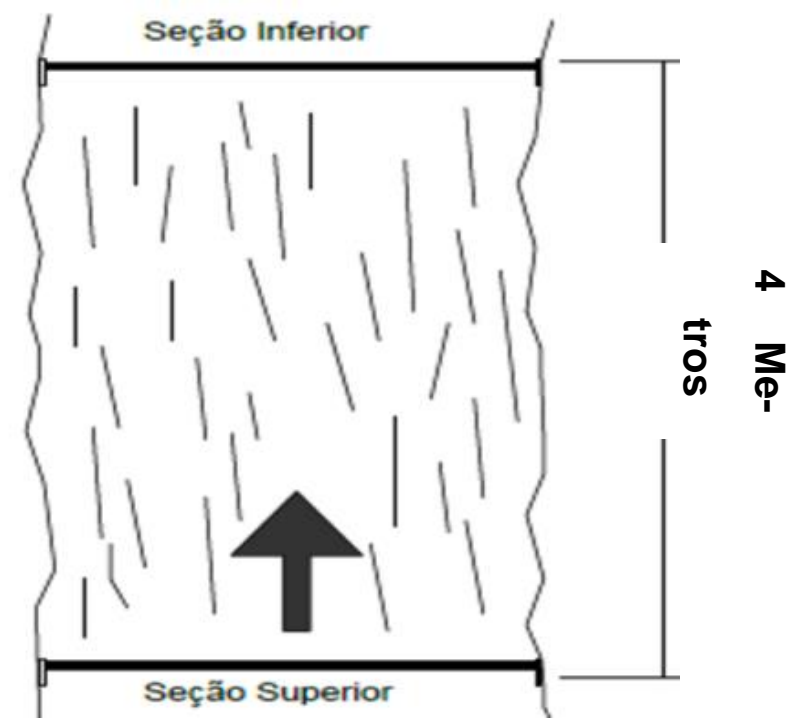

Fonte: (BEZERRA et al., 2017).

3.2.3 Cálculo da área média do trecho do rio $(\mathrm{A})$

Para calcular a área média do trecho do rio foi levada em consideração a largura do rio pela média da profundidade representada na Equação 8 (COLLISCHONN \& DORNELLES, 2013). 
$A=\frac{\mathrm{B}+\mathrm{b}}{2} \times \mathrm{h}$

Onde:

A = Área;

$\mathrm{B}=$ Base maior;

$\mathrm{b}=$ Base menor;

$\mathrm{h}=$ Altura

Foi calculada a área da seção superior e inferior do trecho do rio, somando as duas áreas e dividindo por dois, obtendo a área média do trecho do rio, conforme Figura 4 (BEZERRA et al., 2017; COLLISCHONN \& DORNELLES, 2013).

Figura 4 - Medição da profundidade

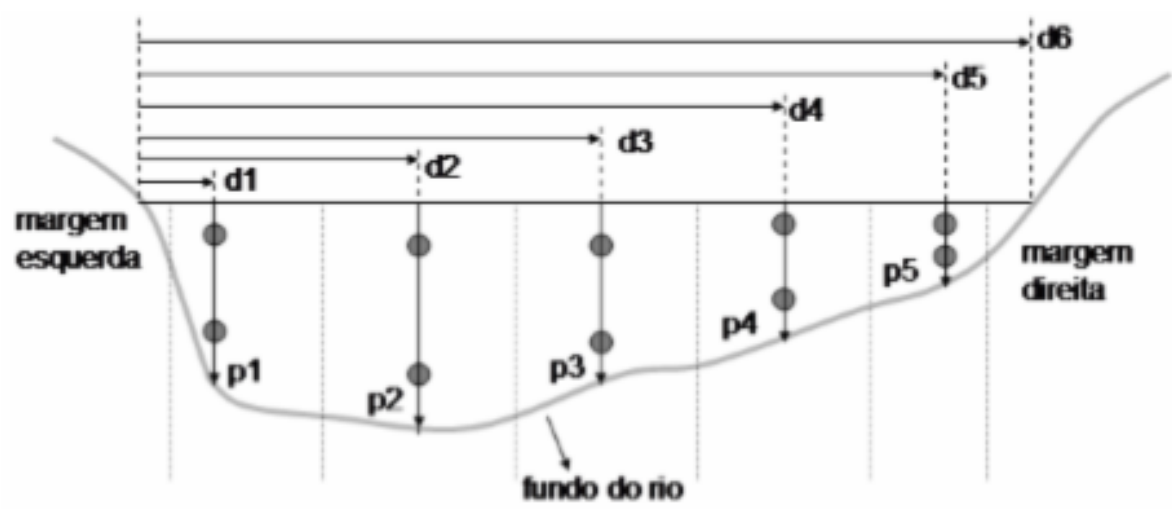

Fonte: Collischonn \& Dornelles (2013)

3.2.4 Medição do tempo (T)

A medição do tempo deu-se ao deslocamento da bola de isopor da seção superior até a seção inferior. Fazendo uso de um cronômetro. Onde o isopor era posicionado na seção superior sem qualquer tipo de obstrução e quando ele era solto o cronômetro também era acionado. O cronometro parava quando o isopor ultrapassava totalmente a corda na seção inferior. Sendo esta medição feita no mínimo por três vezes. O resultado final da medição do tempo era através da média de todas as repetições sendo que quanto mais repetição, mais precisa ficava os resultados que foram representados pelo T na fórmula para o cálculo da vazão (BEZERRA et al., 2017). 


\subsection{Régua linimétrica}

A partir da avaliação da topografia do terreno com o auxilio dos materiais de apoio procedeu-se a instalação da régua linimétrica com nivelamento a partir da mangueira de nível, em escada de 0,50 m ou 1 m conforme Ana (2016). Na Figura 5, está demostrando como é feito o nivelamento das réguas.

Figura 5 - Nivelamento das réguas

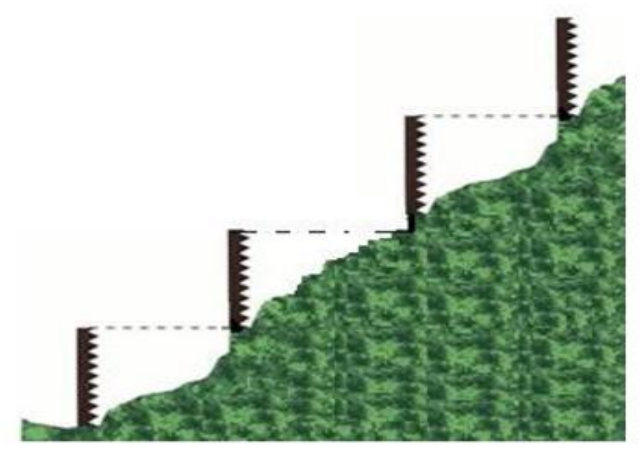

Fonte: ANA (2016).

A quantidade de réguas que foi colocado na estação fluviométrica dependeu de análise feita no local, onde tinha que abranger tanto na estiagem quanto na cheia. Foi colocado dois lances de régua com marcação de 0 a 1000 centímetros no P2. As duas réguas foram numeradas na parte superior, pois quando a água elevava e cobria a régua, era possível acompanhar o nível da água pela régua seguinte. A leitura seguiu um padrão sendo realizadas apenas as 7 h00 da manhã de cada dia, entre março de 2018 a novembro de 2018, totalizando 9 meses. Ainda para a instalação foram tomados alguns cuidados como o leito do córrego ser retilíneo e bem estável.

\subsection{Curva-chave}

A partir dos cálculos de vazão do córrego criminoso através do método Flutuador e dos registros feitos com a régua linimétrica com diferentes níveis e utilizando o programa da Microsoft Excel, calculou-se a curva-chave, sendo os dados de níveis (h) em metros e respectivas vazões $(Q)$ em Litros por segundo, determinou-se uma equação para a Curva-Chave, do tipo potência, descrito na Equação 8: 
$Q=a \cdot\left(h-h_{o}\right)^{m}$

Onde: $Q$ é a vazão $\left({\mathrm{L} . \mathrm{S}^{-1}}^{-1}\right)$;

$h$ é a cota $(m)$;

$h_{o}$ é a cota $(\mathrm{m})$ quando a vazão é zero;

$a$ e $m$ são parâmetros ajustados por um critério de minimização de erros.

Utilizando-se o processo de linearização por logaritmos e o método de mínimos quadrados. Foram estimados vários valores de ho, escolhendo o que conduziu ao melhor coeficiente de relação R (BARTELS et al., 2010; COLLISCHONN \& TASSI, 2008).

\subsection{Característica Fisiográfica}

Utilizando o software QGIS 2.18.13 foi determinada o cumprimento do talvegue, a área e o perímetro da microbacia com o auxilio da calculadora de campo. Para obter a declividade e a elevação do curso principal utilizou-se a ferramenta Profile Tool.

\section{ANÁLISE E DISCUSSÃO DOS RESULTADOS}

O Gráfico 1, demostra o resultado da vazão observada em L.s ${ }^{-1}$ dos dois pontos de medições, sendo P1 próximo da nascente e P2 próximo da Foz. Apresentando a vazão máxima, mínima e média.

Gráfico 1 - Demonstração da vazão máxima, mínima e média entre os pontos de medições P1 e P2

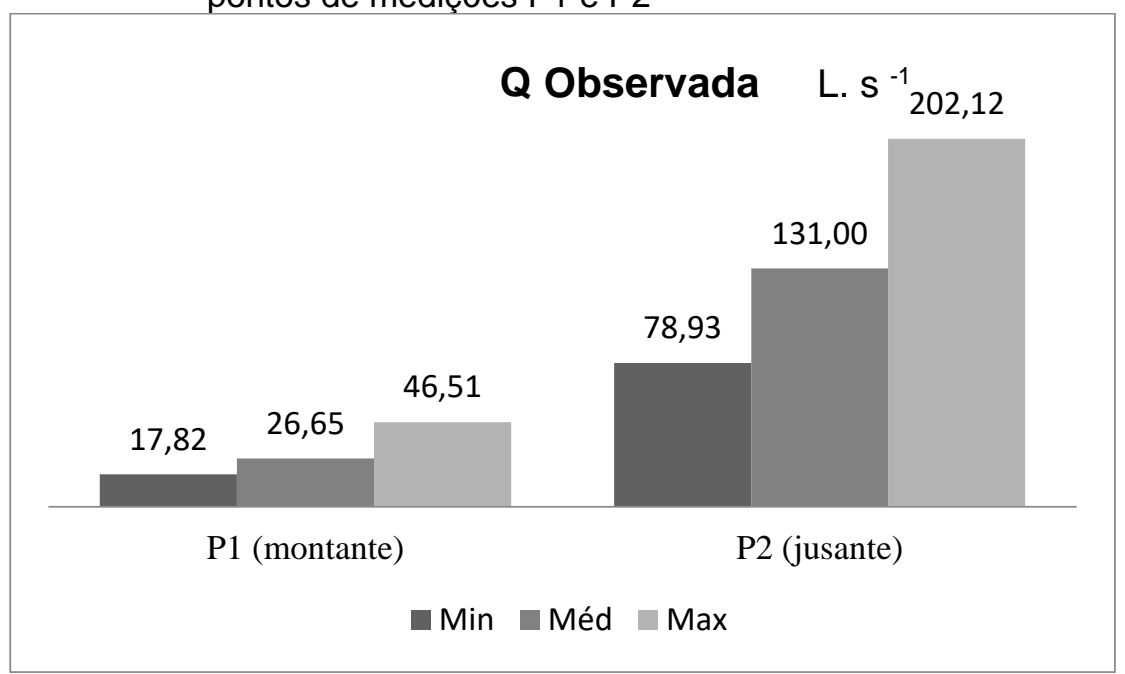

Fonte: Autoria própria 
Conforme demostrado no gráfico 1 , os resultados apresentaram significativa variação entre $\mathrm{P} 1$ e P2, sendo esperado no $\mathrm{P} 1$ tivesse a quantidade de vazão maior do que P2, devido as característica que a bacia apresenta, pois de acordo com Güntzel et al. (2011) o córrego sofreu bastante interferência antrópica, perdendo a maior parte das áreas de APP, utilizando estas áreas nas margens do córrego para pastagem do gado e desviando água do córrego para abastecer açudes, mas nos resultado o $\mathrm{P} 2$ recebe uma quantidade de água bem maior do que $\mathrm{P} 1$, tendo como justificativa as duas erosões que estão nas margens esquerda do córrego, onde já alcançaram o lençol freáticos, fornecendo assim uma lâmina d'água do lençol freático e dos esgotos irregulares que provem dos bairros próximos as erosões, não foi levado em consideração as áreas impermeável dos bairros, pois as medições foram realizadas em dias sem chuva e as áreas impermeável tem influência direta no período chuvoso (Figura 6), ainda há uma contribuição do afluente que se encontra na margem direita do córrego, sendo que este afluente se encontra bastante antropizado contribuindo apenas nos períodos de chuvas. De acordo com Corrêa et al. (2018), nas margens dos córregos onde tem desmatamento e ocupação do solo de forma irregular, estas áreas se tornam impermeável, dificultando na infiltração e interceptação da água, favorecendo da oscilação da vazão. No P1 as margens encontram preservadas, com baixa intensidade antrópicas e Barboza (2010) afirma que quanto mais preservada as margens do córrego maior a taxa de infiltração e disponibilidade de água.

Já a vazão máxima e mínima de acordo com Teodoro et al. (2013), permitirá saber a quantidade de carga lançada que o corpo d'água suportará, sendo este dados importante no córrego criminoso, pois o mesmo já recebe concentrações altas de esgoto da cidade através das erosões nas margens esquerda do córrego, conforme Figura 6. Na Figura 7 estão algumas áreas que apresentam impactos nas margens do córrego criminoso. 
Figura 6 - Erosões provindas dos bairros pertencentes à bacia hidrográfica seguindo em direção ao córrego criminoso

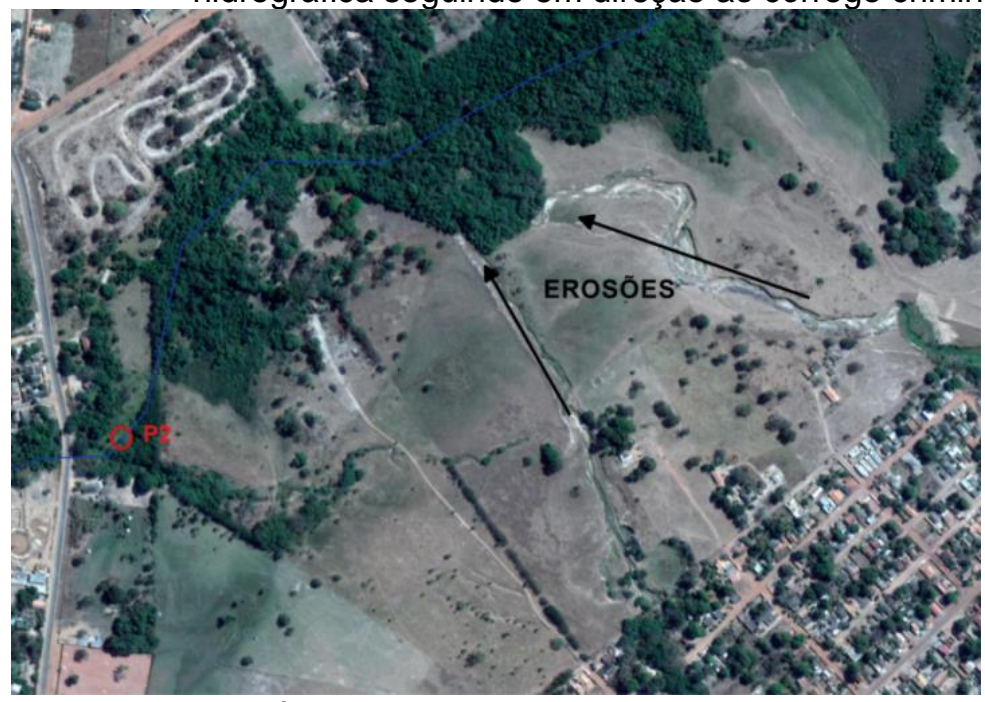

Fonte: Autoria Própria

Figura 7 - Áreas impactadas próximo ao córrego criminoso. Sendo: $a$ - Entulhos nas margens da erosão. $b$ - Lixos depositados no córrego. c - Construções e pastagens. d - Esgoto irregular
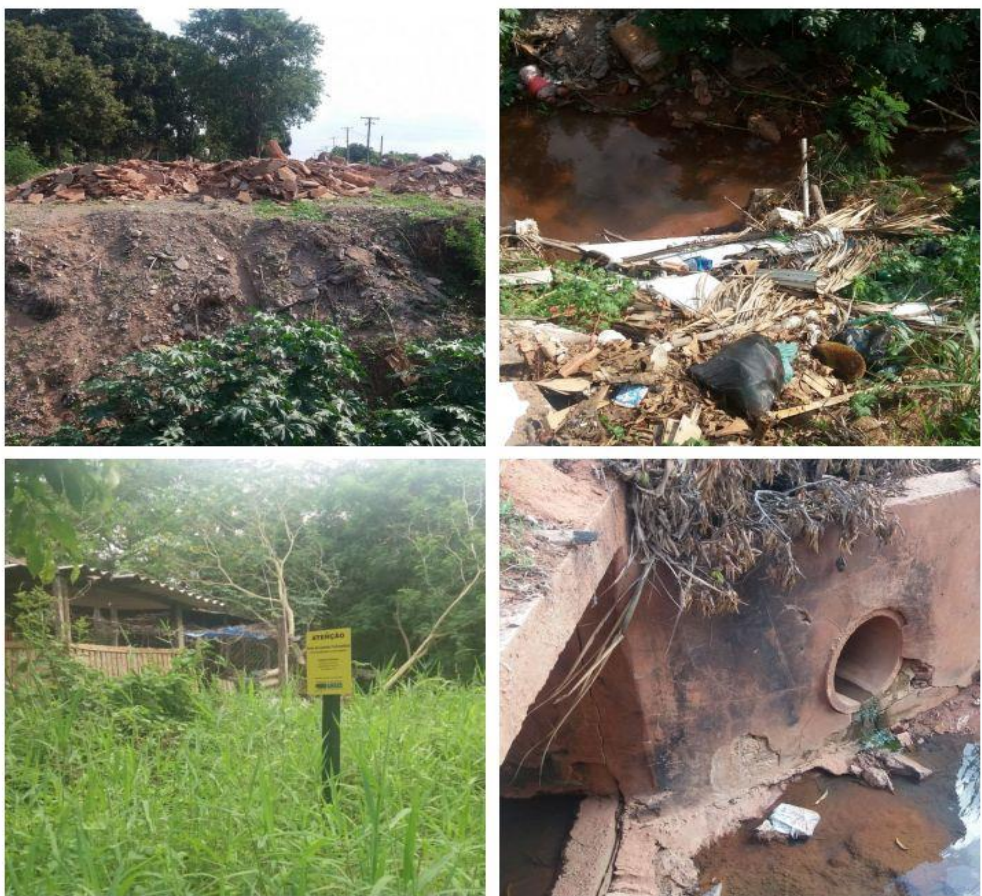

Fonte: Autoria Própria

No Gráfico 2, estão apresentados os valores da vazão dos pontos P1 e P2 comparando com a precipitação, sendo que os valores dos pontos são pontuais, onde foram medidas pelo método flutuador uma vez por mês representando o mês em questão, já os valores dos dados da precipitação foram fornecidos da Cemtec - MS (n.d.), e feita à soma de toda a precipitação acumulada em cada mês. 
Gráfico 2 - Medição dos pontos P1, P2 e da precipitação durante os meses de dezembro de 2017 a outubro de 2018.

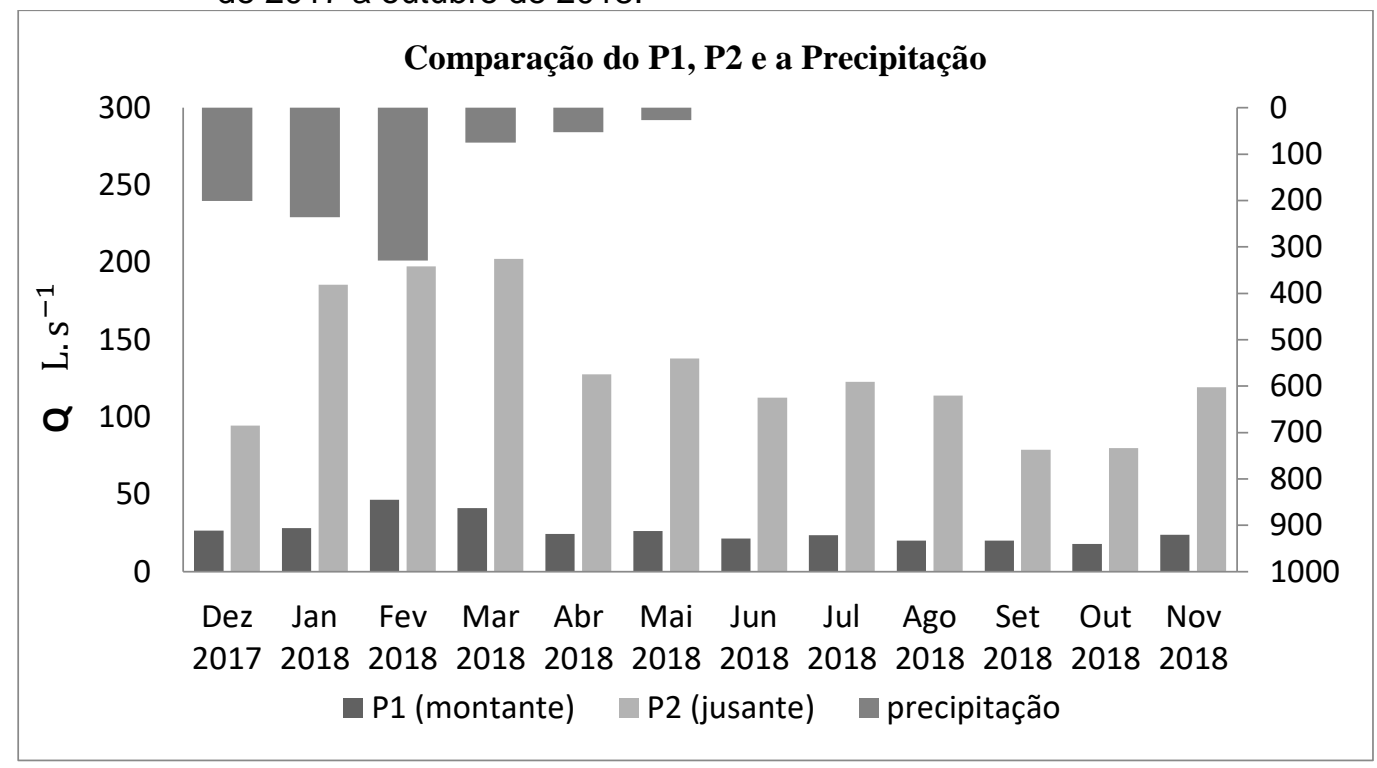

Fonte: Cemtec (n.d.)

Neste gráfico 2 apresentado, a precipitação ocorreu com mais intensidade nos meses de dezembro de 2017 a março de 2018, vindo a diminuir seu volume nos meses seguinte até Maio, sendo que, a partir de junho a precipitação foi zero, ficando mais de 90 dias sem chuva na bacia, e nas medições foram apresentados valores maiores de água nos períodos de estiagem, mostrando assim a capacidade de armazenagem de água no subsolo, e como esta água armazenada ajuda na continuidade da vazão durante os períodos sem chuvas.

A figura 8 demostra como ficou a instalação da régua linimétrica no $P 2$, sendo que foi possível fazer o acompanhamento, complementado os resultados da vazão obtidos pelo método Flutuador.

Figura 8 - Régua linimétrica instalada no córrego criminoso

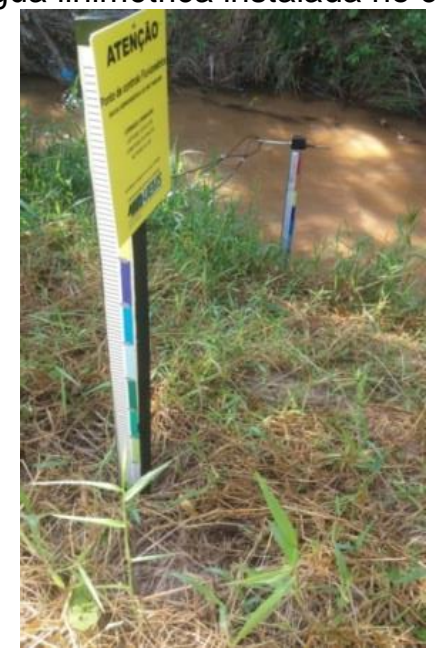

Fonte: Autoria própria 
A variação da régua entre a máxima, mínima e média está apresentada no Gráfico 03 , onde foram coletados os dados diariamente no período da manhã, mostrando assim que os valores da vazão mínima marcado na régua manteve um padrão com pouca oscilação, diferente da máxima que mostrou do período chuvoso para a estiagem um decréscimo, chegando ao mês de setembro um valor bem próximo da mínima, saindo assim de uma estiagem de mais de 3 meses.

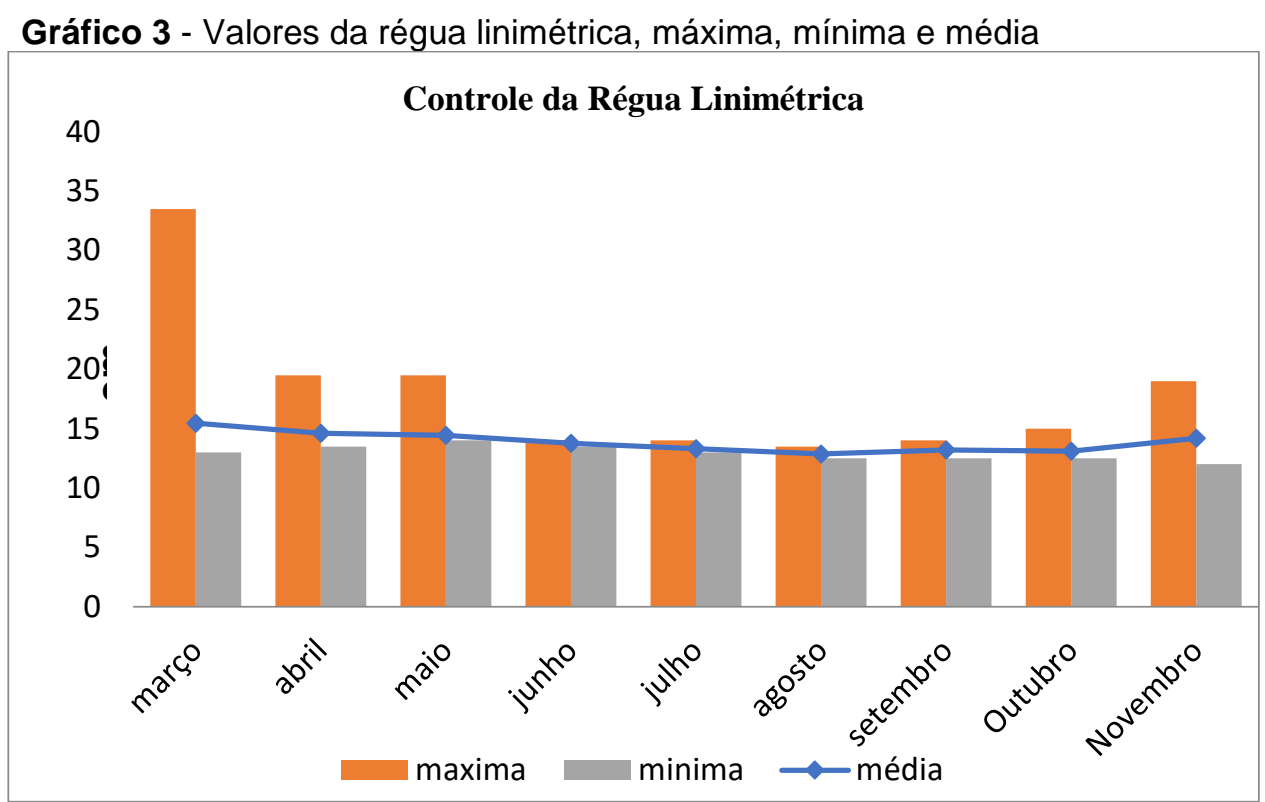

Fonte: Autoria Própria

No córrego criminoso em sua margem esquerda apresenta erosões de grande porte, alcançando o lençol freático contribuindo com a vazão do córrego junto com esgoto proveniente dos bairros pertencente à micro bacia. De acordo com Güntzel et al. (2011) a substituição da vegetação natural pelas pastagens nas proximidades do córrego facilitou o inicio destas erosões, contribuindo para o assoreamento do córrego. Segundo Carneiro et al. (2009), o solo na área é Neossolo Quartizerênico apresentando capacidade baixa para reter água, muitas limitações para uso agrícola e com o nível de alumínio sempre em nível tóxicos, sendo preocupante na micro bacia pois é predominante a criação de gado na região, outro problema apresentado é o represamento das nascentes para fornecer água ao gado, retirando também as cercas para que o gado chegue até o leito principal fazendo grande áreas de pisoteio, desviam água do canal principal para abastecer tanques para criação de peixes, sem qualquer tipo de estudo de vazão. Na Figura 9, foram apresentados alguns pontos de localização das represas e erosões. 
Figura 9 - Áreas críticas que influenciam na vazão do córrego.

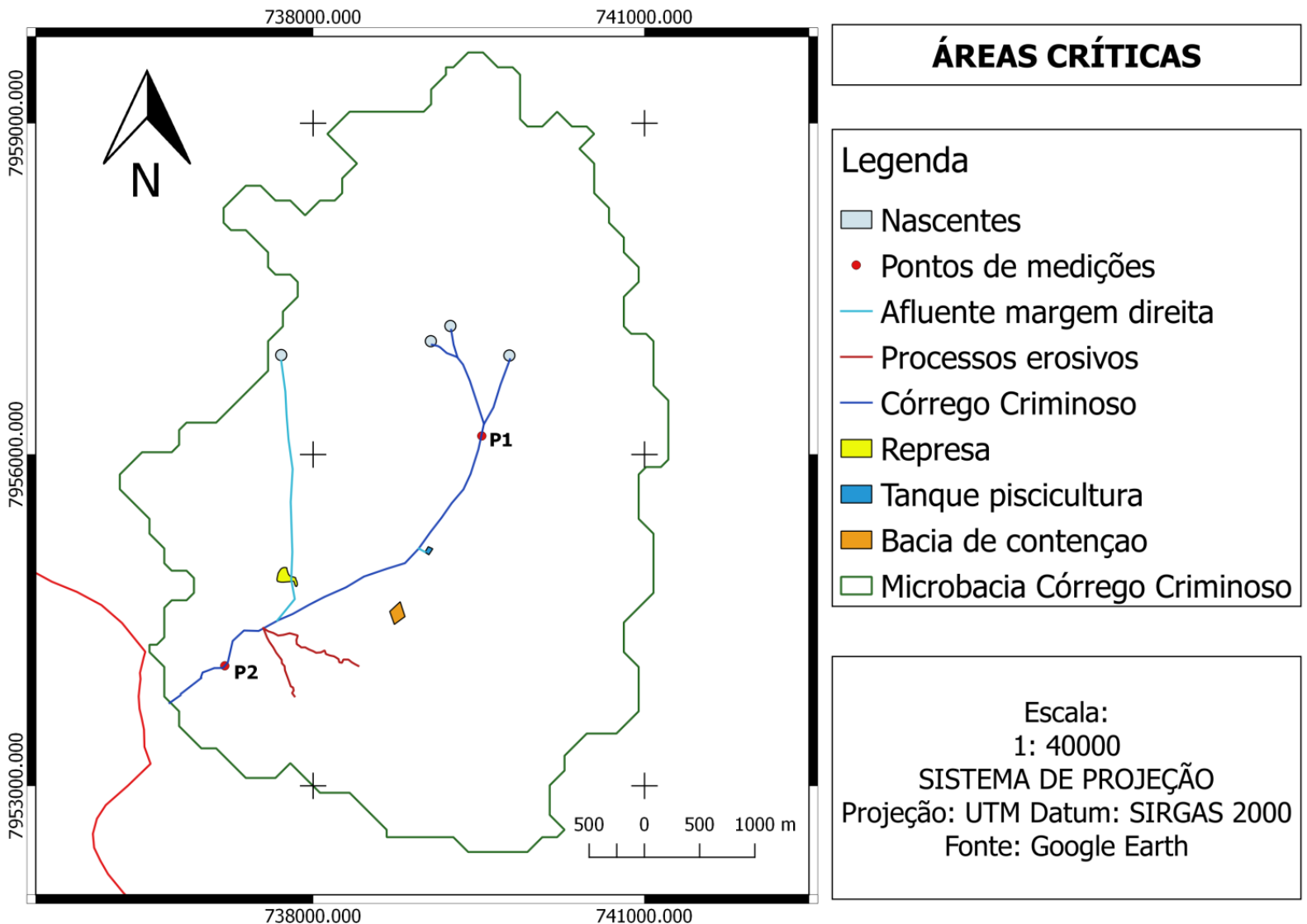

Fonte: Autoria própria

\section{Curva-chave}

Foram atribuídos diferentes valores de ho variando de 0 a 0,12. Para cada ho testado foi obtido um valor de $\mathrm{R}^{2}$ diferente. Portanto, verificou-se que o melhor ajuste foi obtido com o ho=0,11, conforme demonstrado no Gráfico 04. Assim verificou-se que o ho = 0,11 obteve o maior valor de $R^{2}$.

A tabela 1 demonstra o processo de linearização logarítmica e mínimos quadrados obtidos aplicando-se o h0 de 0,11. A partir desse processo foram obtidos os parâmetros a e b decorrentes do erro quadrático mínimo. 
Gráfico 4 - Valores de coeficiente $R^{2}$ em relação aos valores de cota ho.

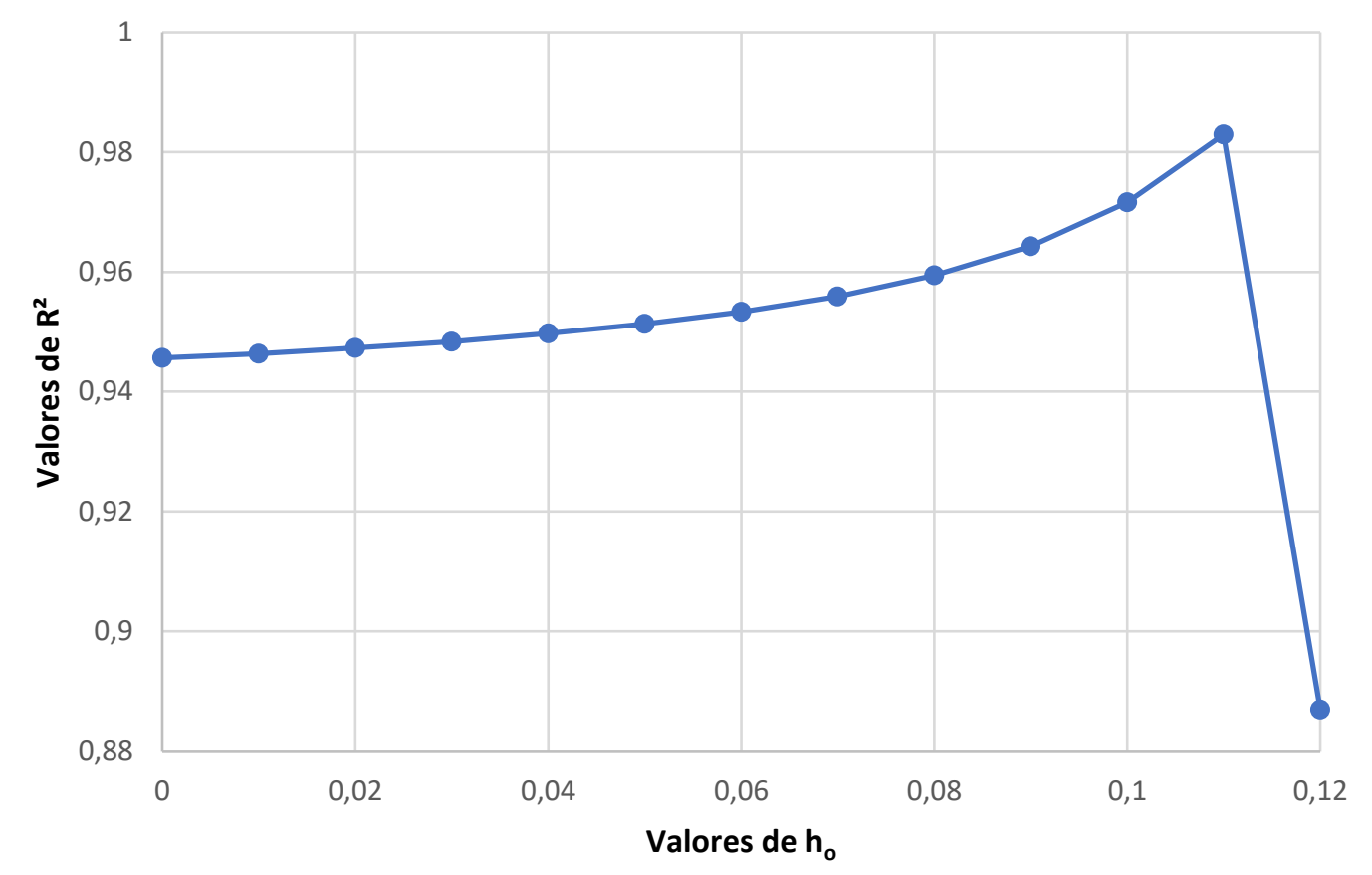

Fonte: Autoria própria

Tabela 1 - Processo de linearização logarítmica

\begin{tabular}{|c|c|c|c|c|c|c|c|c|}
\hline Núm & $h(m)$ & $\begin{array}{l}h_{0}= \\
Q(L / s)\end{array}$ & $\begin{array}{c}0,11 \\
Y=\ln Q\end{array}$ & $h-$ ho & $X=\operatorname{Ln}(h-h o)$ & $\mathbf{X}^{2}$ & $\mathbf{Y}^{2}$ & $X Y$ \\
\hline 1 & 0,12 & 78,93 & 4,36856 & 0,01 & $-4,60517$ & 21,20759 & 19,08433 & $-20,11797$ \\
\hline 2 & 0,12 & 78,93 & 4,36856 & 0,01 & $-4,60517$ & 21,20759 & 19,08433 & $-20,11797$ \\
\hline 3 & 0,12 & 79,99 & 4,38190 & 0,01 & $-4,60517$ & 21,20759 & 19,20106 & $-20,17940$ \\
\hline 4 & 0,13 & 113,81 & 4,73453 & 0,02 & $-3,91202$ & 15,30392 & 22,41578 & $-18,52159$ \\
\hline 5 & 0,13 & 122,62 & 4,80909 & 0,02 & $-3,91202$ & 15,30392 & 23,12735 & $-18,81327$ \\
\hline \multirow[t]{3}{*}{6} & 0,14 & 137,87 & 4,92631 & 0,03 & $-3,50656$ & 12,29595 & 24,26854 & $-17,27440$ \\
\hline & & Soma= & 27,58896 & & $-25,14611$ & 106,52657 & 127,18139 & $-115,02460$ \\
\hline & & Média= & 4,59816 & & $-4,19102$ & 17,75443 & 21,19690 & $-19,17077$ \\
\hline
\end{tabular}

Fonte: Autoria própria

Como resultado plotou-se o gráfico 6 da relação do logarítmica da vazão $Y=I n$ $Q$ em relação ao logaritmo do produto da subtração da altura observada menos a altura ho $\mathrm{X}=\ln \left(\mathrm{h}-\mathrm{h}_{0}\right)$, resultando na equação da reta que permitiu obter os parâmetros a e b. 
Gráfico 5 - Regressão linear do $\ln Q$ em relação ao $\ln \left(h-h_{0}\right)$

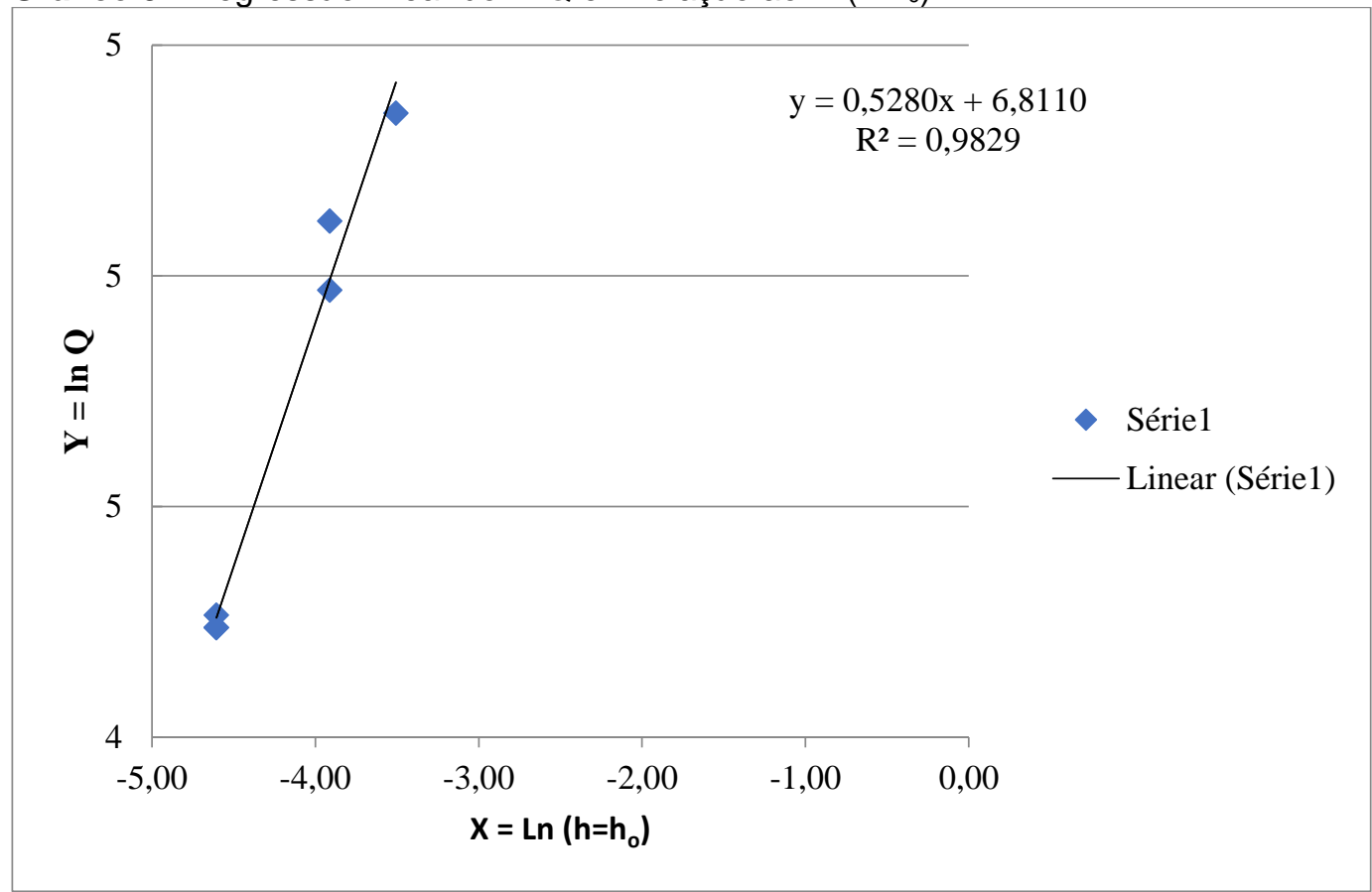

Fonte: Autoria própria

Assim, sendo:

$Y=a_{0}+b_{0} \cdot X$

$\mathrm{Y}=6,811+0,528 . \mathrm{X}$

Sabendo:

$Y=\operatorname{Ln} Q$

$\mathrm{X}=\operatorname{Ln}(\mathrm{h}-0,11)$

$a_{0}=\operatorname{Ln} a$

$b_{0}=m$

Então:

$\operatorname{Ln} Q=6,811+0,528$. Ln $(h-0,11)$

Aplicando o exponencial em ambos os lados, temos:

$e^{\operatorname{Ln} Q}=e^{6,811+0,528} \cdot \operatorname{Ln}(h-0,11)$

Resolvendo, temos a equação da Curva-Chave:

$\mathrm{Q}=907,7781 .(\mathrm{h}-0,11)^{0,528}$

Dados para a entrada na Curva-Chave do córrego Criminoso são: cota em metros e a Vazão será calculada em L.s ${ }^{-1}$. 
A curva de permanência representa a relação da vazão com as frequências que estas podem ocorrer, mostrando se elas foram superadas ou igualadas. A curva de permanência é importante na hidrologia, pois demostra extremos da vazão.

No córrego criminoso foi elaborada a curva de permanência a partir dos dados da régua linimétrica, apresentando o valor máximo de 609,32 L.S ${ }^{-1}$., a média de 138,78 L.S ${ }^{-1}$ e a mínima de 98,85 L.S ${ }^{-1}$, sendo a Q90 115 L.S $^{-1}$ e a Q95 99 L.S $^{-1}$. Conforme demostrado no Gráfico 6.

Gráfico 6 - Curva de permanência do córrego criminoso para o período de dezembro de 2017 a outubro de 2018.

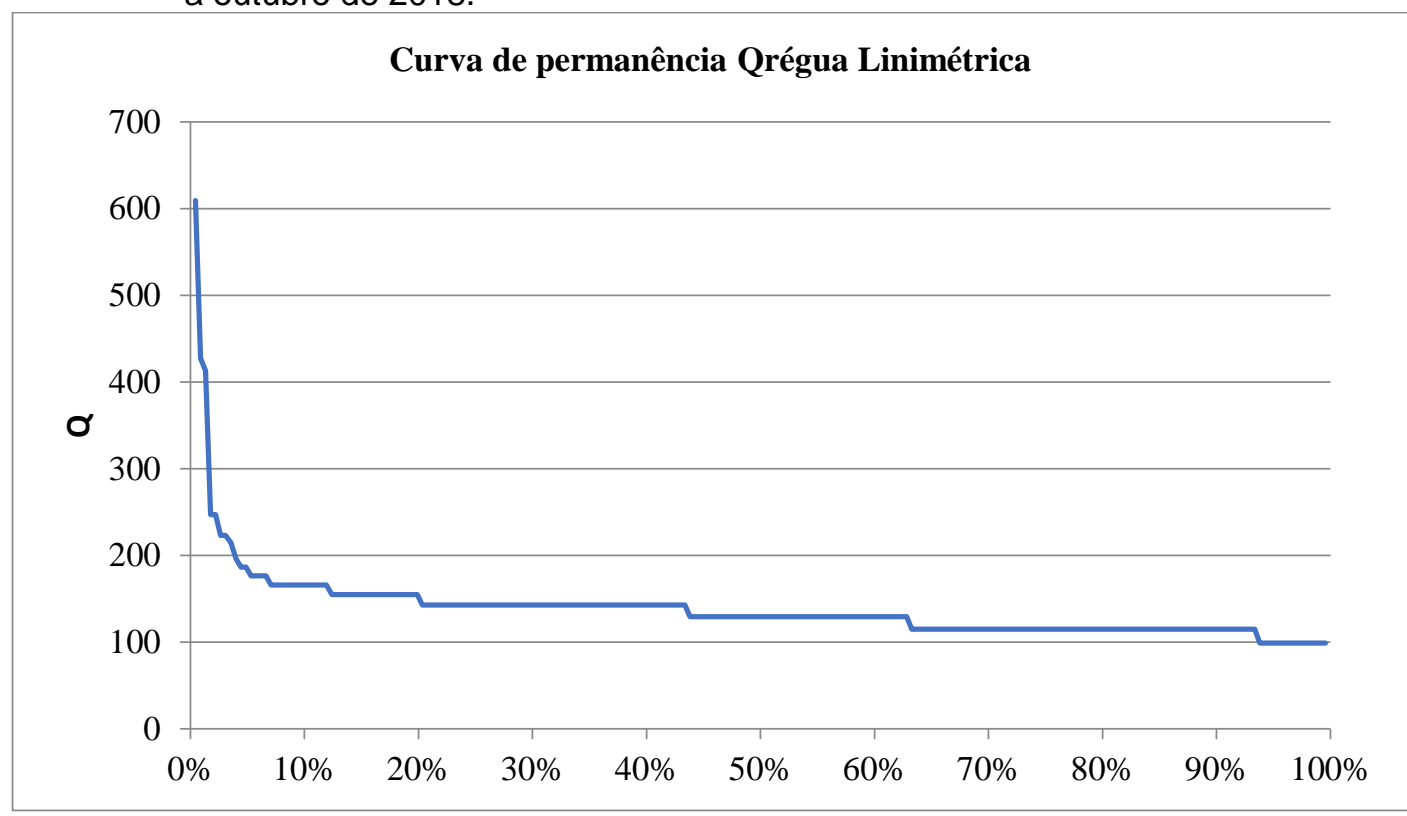

Fonte: Autoria própria

Ao realizar a caracterização fisiográfica da micro bacia do córrego criminoso foram obtidos os parâmetros área de drenagem, perímetro, comprimento do talvegue, elevação máxima, elevação média, elevação mínima, declividade do talvegue, coeficiente de compacidade, fator de forma, densidade de drenagem e tempo de concentração Kirpch. Os resultados e unidade de medidas são apresentados no Tabela 2. 
Tabela 2 - Característica fisiográfica da micro bacia do córrego criminoso

\begin{tabular}{lcc}
\hline \multicolumn{1}{c}{ Características } & Valor & Unidade \\
\hline Área de Drenagem & 25,530 & $\mathrm{~km}^{2}$ \\
Perímetro & 28,429 & $\mathrm{~km}$ \\
Comprimento talvegue & 4,755 & $\mathrm{~km}$ \\
Elevação Máxima & 267 & $\mathrm{~m}$ \\
Elevação Média & 244 & $\mathrm{~m}$ \\
Elevação Mínima & 200 & $\mathrm{~m}$ \\
Declividade do talvegue & 0,014 & $\mathrm{~m} . \mathrm{m}^{-1}$ \\
Coeficiente de Compacidade & 1,58 & - \\
Fator de Forma & 1,13 & - \\
Densidade de Drenagem & 0,30 & $\mathrm{~km} \cdot \mathrm{km}^{-2}$ \\
Tempo de Concentração Kirpch & 68 & $\mathrm{~min}$ \\
\hline Fonte: Autoria própria & &
\end{tabular}

Interpretando a características morfométrica da micro bacia do córrego criminoso, possibilita classifica-la como uma micro bacia de acordo com Faustino (1996) por possuir área inferior a $100 \mathrm{~km}^{2}$, com tempo de concentração de 68 minutos informação importante para a determinação de Chuvas Intensas na micro bacia, ainda a micro bacia apresentando uma drenagem de $0,30 \mathrm{~km} / \mathrm{Km}^{-2}$, considerada pobre, sendo que para ser enquadrada como bacia com drenagem regular segundo Faustino

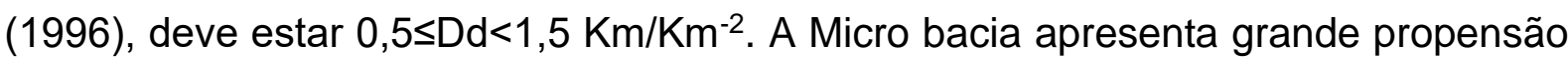
a enchentes, pois a mesma apresentou Fator de Forma 1,13 e para não ser sujeita a grandes enchentes teria que apresentar valor $>0,50$.

\section{CONSIDERAÇÕES FINAIS}

Os resultados demonstraram que o método do flutuador foi satisfatório como ferramenta para acompanhamento de vazão em córregos urbanos de pequeno porte.

O comportamento fluvial do córrego criminoso no período apresentou Q90 de 115 L.S $^{-1}$ e Q95 de 99 L.S $^{-1}$. Esse comportamento sofreu influência da precipitação durante o período de cheia na bacia de contribuição.

A curva-chave do tipo potência mostrou-se adequada para determinação da vazão a partir da cota linimétrica, permitindo o monitoramento diário da vazão do curso d'água.

Os parâmetros da curva-chave para o córrego criminoso são $h_{0}=0,11$, $a=907,7781$, e $m=0,528$, aplicável tanto no período de estiagem quanto no período chuvoso. 
O córrego criminoso recebe grande quantidade de agua pluvial e efluente domiciliar dos bairros próximo, sendo um dos fatores a falta de planejamento urbano, sendo necessária uma revisão no Zoneamento Ambiental e do Plano Diretor do Município de Coxim.

A partir do comportamento fluvial poderão ser adotadas medidas de contenção aos processos erosivos que lançam sedimento no curso d'água, bem como poluição. Recomenda-se a manutenção da bacia de contenção de água e sedimentos para um melhor desempenho e a recuperação da mata ciliar e praticas de proteção do solo, como curva de nível e terraceamento.

A micro bacia do córrego criminoso apresentou as seguintes características: tempo de concentração de 68 minutos, Fator de Forma de 1,13 e Densidade de Drenagem de $0,30 \mathrm{Km} / \mathrm{Km}^{-2}$.

\section{REFERÊNCIAS}

ALBUQUERQUE, L. C., AMARAL, P. A. A., VIEIRA, E. O., RODRIGUES, F. M., \& ALMEIDA, R. P. Influência do uso e ocupação do solo sobre a vazão do alto da bacia do Rio Verde Grande-MG/Influence of land use on streamflow from the upper watershed of Rio Verde Grande-MG. Caderno de Ciências Agrárias, v. 10, n. 2, p. 15-22, 2018.Disponível em: https://periodicos.ufmg.br/index.php/ccaufmg/article/view/3031

AGÊNCIA NACIONAL DE AGUAS - ANA . Medindo as Águas do Brasil: noções de plu e fluviométrica. 2016. Disponível em: https://capacitacao.ead.unesp.br/dspace/bitstream/ana/122/1/ Apostila Medindo as \%C3\%81guas ANA.pdf. Acesso em: 20 maio 2018.

AGÊNCIA NACIONAL DE AGUAS - ANA. Relatório Conjuntura. 2017. Disponível em: http://conjuntura.ana.gov.br/static/media/conjuntura completo.caf2236b.pdf. Acesso em: 23 maio 2018

AGÊNCIA DE DESENVOLVIMENTO AGRÁRIO E EXTENSÃO RURAL - CEMTEC (n. d.). Banco de Dados. Disponível em: http://www.cemtec.ms.gov.br/?page id=15. Acesso em: 15 jun. 2018.

BARBOZA, G. C. Monitoramento da qualidade e disponibilidade da água do Córrego do Coqueiro no noroeste paulista para fins de irrigação. (Dissertação de mestrado). Faculdade de Engenharia, Universidade Estadual Paulista, 2010.

BARRETO, L. V., FRAGA, M. S., BARROS, F. M., ROCHA, F. A., AMORIM, J. S., CARVALHO, S. R.; BONOMO, P.; \& SILVA, D. P. Relação entre vazão e qualidade da água em uma seção de rio. Revista Ambiente \& Água, v. 9, n. 1, p. 118-129, 2014. https://dx.doi.org/10.4136/ambi-agua.1278

BARTELS, G. K., BESKOW, S., AQUINO, L. S., TAVARES, V. E. Q., \& TIMM, L. C. Avaliação dos dados de vazão gerados pela curva-chave no Arroio Pelotas (Ponte Cordeiro de 
Farias). In: Congresso de Iniciação Científica, 19. ENCONTRO DE PÓS-GRADUAÇÃO, 12. Mostra Científica, 2., 2010. [Anais...] (p. 1-4). Pelotas, RS, 2010.

BEZERRA, J. C. F., DIAS, J. G. S., OLIVEIRA, A. T. S., RIBEIRO, A. T., \& DANIEL, R. (Medição de vazão em um canal fluvial utilizando o método do flutuador. In: CONGRESSO INTERNACIONAL DAS CIÊNCIAS AGRARIAS, 2., 2017. [Anais...] COINTR- PDVAgro (p. 1-5). Mossoró, RN, 2017.

BORBA, N. Z., \& BAYER, D. A.A água como bem jurídico econômico. Temiminós Revista Científica, v. 5, n. 1, p. 97-110, 2015. Disponível: http://oaji.net/journal-archivestats.html?number $=1424$.

BRUSA, L. C., \& CLARKE, R. T. Erros envolvidos na estimativa da vazão máxima utilizando curva-chave. Caso de estudo: Bacia do Rio lbicuí, RS. Revista Brasileira de Recursos Hídricos, v.4, n. 3, p. 91-95, 1999. Disponível em: http://dx.doi.org/10.21168/rbrh.v4n3.p91-95.

CABRAL, S. L., REIS, R. S., \& JUNIOR, C. R. F. Avaliação do efeito da urbanização na produção de sedimentos da bacia do rio Jacarecica/AL mediante uso de modelo hidrossedimentológico distribuído. Revista Brasileira de Ciência do Solo, v. 37, n. 4, p. 1074-1080, 2013. http://dx.doi.org/10.1590/S0100-06832013000400024

CARNEIRO, C., AURÉLIO, M., SOUZA, D., REIS, E. F., PEREIRA, E. S., AZEVEDO, H., \& WASTSON, R. Atributos físicos, químicos e biológicos de solo de cerrado sob diferentes sistemas de uso e manejo. Revista Brasileira de Ciência do Solo, v. 33, n. 1, p. 147-157, 2009. http://dx.doi.org/10.1590/S0100-06832009000100016

CARVALHO, T. Técnicas de Medição de Vazão por Meios Convencionais e Não Convencionais. Revista Brasileira de Geografia Física, v. 1, n. 1, p. 73-85, 2008. https://periodicos.ufpe.br/revistas/rbgfe/article/view/232608

CARVALHO, W. M., VIEIRA, E. O., ROCHA, J. M. J., PEREIRA, A. K. S., \& CARMO, T. V. B. (Caracterização fisiográfica da bacia hidrográfica do córrego do malheiro, no município de Sabará - MG. Irriga, Botucatu, v. 14, n. 3, p. 398-412, 2009. https://doi.org/10.15809/irriga.2009v14n3p398-412

COLLISCHONN, W., \& TASSI, R. Introduzindo hidrologia. 5. ed.Rio Grande do Sul, 2008. V.1.

COLLISCHONN, W., \& DORNELLES, F. Hidrologia para engenharia e ciências ambientais: Associação Brasileira de Recursos Hídricos. 2. ed. Porto Alegre, 2013. V. 1.

CORRÊA, R. H. A., VAZQUEZ, G. H., \& VANZELA, L. S. Projeto estratégico de ocupação do fundo de vale do córrego da Aldeia no perímetro urbano de Fernandópolis/SP. Revista Brasileira de Gestão Urbana, v.10, n. 2, p. 458-472, 2018. https://dx.doi.org/10.1590/2175$\underline{3369.010 .002 . a 015}$

EMPRESA BRASILEIRA DE PESQUISA AGROPECUÁRIA - EMBRAPA. Centro Nacional de pesquisa de solos (Rio de Janeiro, RJ): sistema brasileiro de classificação de solos. 2. ed. Rio de Janeiro: EMBRAPA-SPI, 2006. Disponível em: https://www.agrolink.com.br/downloads/sistema-brasileiro-de-classificacao-dos-solos2006.pdf. Acesso em: 26 jul. 2018,

FAUSTINO, J. Planificación y gestión de manejo de cuencas. Turrialba: CATIE, 1, 90, 1996. 
GALVÍNCIO, J. D., \& SOUSA, F. Uso do modelo TOPAZ para a caracterização fisiográfica da bacia hidrográfica do Açude Epitácio Pessoa. Revista Brasileira de Recursos Hídricos, Porto Alegre, v. 9, n. 4, p. 69-75, 2004. http://dx.doi.org/10.21168/rbrh.v9n4.p69-75

GÜNTZEL, A. M., DIAS, N. R., COERTJENS, C. M., SILVA, G. C., \& VIEIRA, E. A. Análise fitossociológica de um remanescente de vegetação na microbacia do Córrego Criminoso (Bacia do Rio Taquari, Coxim, MS, Brasil): subsídios para a recomposição da vegetação. Acta Botanica Brasilica, v. 25, n. 3, p. 586-592, 2011. https://dx.doi.org/10.1590/S0102$\underline{33062011000300011}$

JOIA, P. R., ANUNCIAÇÃO, V. S. D., \& PAIXÃO, A. A. D. Implicações do uso e ocupação do solo para o planejamento e gestão ambiental da Bacia Hidrográfica do Rio Aquidauana, Mato Grosso do Sul. Interações (Campo Grande), v. 19, n. 2, p. 343-358, 2018. http://dx.doi.org/10.20435/inter.v19i2.1404

KONCAGÜL, E. Relatório Mundial das Nações Unidas sobre o Desenvolvimento dos Recursos Hídricos, 2017. Programa Mundial das Nações Unidas para Avaliação do Recurso Hídrico Gabinete do Programa de Avaliação Global da Água. Divisão de Ciências Hídricas. 2017. Disponível em: http://unesdoc.unesco.org/images/0024/002475/247552por.pdf. Acesso em: 22 jun. 2018.

LIMA, M. H. R., \& MACEDO, A. P. B. A. Traçado das curvas-chaves de estações hidrométricas localizadas na bacia hidrográfica do rio Piauí, no estado de Sergipe. Scientia Plena, v.13, n. 10, p. 2-7, 2077. http://dx.doi.org/10.14808/sci.plena.2017.109911

ORGANIZAÇÃO DAS NAÇÕES UNIDAS. Declaração de Dublin sobre Água e Desenvolvimento Sustentável - ONU 1992a.Disponível em: http://www.abcmac.org.br/files/downloads/declaracao de dublin sobre agua e desenvolvimento sustentavel.pdf. Acesso em: 30 ago. 2018.

PALHARES, J. C. P., RAMOS, C., KLEIN, J. B., LIMA, J. M. D., MULLER, S., \& CESTONARO, T. Medição da vazão em rios pelo método do flutuador. Embrapa Suínos e Aves. 2007. Disponível em: https://www.infoteca.cnptia.embrapa.br/handle/doc/443939. Acesso em:_29 jun. 2018.

RIZZARDI, A. S., BERLING, F., DULAC, V., PAIVA, J. B. D., \& TASSI, R. Comparação de métodos de extrapolação da curva-chave para estação fluviométrica de Restinga Seca - RS. In: CONGRESSO INTERNACIONAL DE TECNOLOGIAS PARA O MEIO AMBIENTE. 3., 2012. [Anais...] (p. 1-8). Bento Gonçalves, RS, 2012.

SANTOS, A. M., TARGA, M. S., BATISTA, G. T., \& DIAS, N. W. Análise morfométrica das sub-bacias hidrográficas Perdizes e Fojo no município de Campos do Jordão, SP, Brasil.

Revista Ambiente \& Água - An Interdisciplinary Journal of Applied Science, v. 7, n. 3, p. 195-211, 2012. http://dx.doi.org/10.4136/ambi-agua.945

SANTOS, G. O., SILVA, A. A., BRAZ, A. R. C., \& CARNEIRO, F. M. Caracterização morfométrica das bacias hidrográficas inseridas no município de Rio Verde, Goiás, como ferramenta ao planejamento urbano e agrícola. Geografia Ensino \& Pesquisa, v. 22, n. 17, p. 113, 2018. http://dx.doi.org/10.5902/2236499426572

SANTOS, T. O., SILVA, J. S., VENTURA, G. P. S., SILVA, G., \& VIEIRA, L. J. O. (2018). A utilização dos métodos de medição acústico doppler e flutuador como ferramenta para medição de vazão e velocidade em corpos hídricos-notas de uma experiência de campo. Acta Geográfica, v. 12, n. 28, p. 170-177, 2018. http://dx.doi.org/10.5654/acta.v12i28.4856 
SILVA, J. L., \& TONELLO, K. C. Morfometria da bacia hidrográfica do Ribeirão dos Pinheirinhos, Brotas-SP. Irriga. v. 19, n. 1, p. 103-114, 2014. https://doi.org/10.15809/irriga.2014v19n1p103

SOUSA, C. S., MORAIS, L. R., \& ALMEIDA, F. (2015). Estudo sobre técnicas compensatórias de drenagem urbana: Um estudo de caso na revitalização do córrego cascavel. Revista Nacional de Gerenciamento de Cidades, v. 3, n. 19, p. 111-134, 2015.

http://dx.doi.org/10.17271/2318847231920151049

TEODORO, A., IDE, C. N., RIBEIRO, M. L., BROCH, S. A. O., \& SILVA, J. D. Implementação do conceito Capacidade de Diluição de Efluentes no modelo de qualidade da água QUAL-UFMG: estudo de caso no Rio Taquarizinho (MS). Engenharia Sanitária e Ambiental, v. 18, n. 3, p. 275-288, 2013. https://dx.doi.org/10.1590/S1413-41522013000300010

TUNDISI, J. G. Recursos hídricos no futuro: problemas e soluções. Estudos avançados, v.22, n. 63, p. 7-16, 2008. https://dx.doi.org/10.1590/S0103-40142008000200002

VANELLI, F. M., MONTEIRO, L. R., \& FAN, F. M. (2018). Curva-chave obtida por simulação hidrodinâmica. In: CONGRESO LATINOAMERICANO DE HIDRÁULICA, 2018. [Anais...]. Buenos Aires, 2018. Trabajos completos. Ezeida: Instituto Nacional del Agua. (p. 13521363). Argentina.

WENZEL, D. A., ULIANA, E. M., ALMEIDA, F. T., SOUZA, A. P., MENDES, M. A. D. S. A., \& SOUZA, L. G. S. Características fisiográficas de sub-bacias do médio e alto Rio Teles PiresMT. Revista de Ciências Agroambientais, v. 15, n. 2, p. 123-131, 2017. https://dx.doi: $\underline{10.5327 / Z 1677-606220172193}$ 